\title{
Current Status of Prevention of Hot Corrosion of Boiler Steels with Thermal Spray Coating
}

\author{
Gurdeep Singh, Indermeet Singh and Khushdeep Goyal \\ Department of Mechanical Engineering, Punjabi University, Patiala, Punjab, India \\ E-Mail: gurdeepsingh069@gmail.com
}

\begin{abstract}
In the thermal power plant, various conventional steels are used to manufacture boiler components. Due to high operating temperature of these boilers, these conventional steels are unable to resist hot corrosion. In recent years researchers have used various techniques to resist hot corrosion out of these techniques, thermal spray coating process have gained lot of interest due to the ease of coating, low operating cost, and various other advantages. With these coating processes a thin layer of coating material is developed over steel alloys surface which creates hindrance to penetration of corroding element and hereby reduce corrosion. This paper is an attempt to present a comprehension the study related to hot corrosion of thermal spray coating on boiler steels at high temperatures.
\end{abstract}

Keywords: Thermal Spray, Microstructure, Corrosion, Porosity, Mechanical Properties

\section{INTRODUCTION}

At elevated temperature, accelerated oxidation is experienced by metal and alloys when they are exposed to corrosive environment which leads to deposition of thin film of fused salt on the surface of metal leading to the formation of porous non protective oxide layer on the surface and sulphides inside the substrate as described by the Singh $\mathrm{H}$ et al., [1]. In boiler steel and turbine occurs due to presence of sulphur in coals and oil fuels which produces SO2 and further partially oxidize to SO3.[2] Element causing corrosion enter into boiler tube with the air and with fuel. Sulphur impurity react with $\mathrm{NaCl}$ to formNa2SO4 with in the boiler tube as proposed by DeCrescente and Bornstein $[3,4]$.

$$
2 \mathrm{NaCl}+\mathrm{SO}_{3}+1 / 2 \mathrm{O}_{2} \rightarrow \mathrm{Na}_{2} \mathrm{SO}_{4}+\mathrm{Cl}_{2}
$$

As the higher grade fuel are depleted at a faster pace, therefore residual fuels are beings used for production of energy. Impurities such as $\mathrm{Na}, \mathrm{K}, \mathrm{S}$ and $\mathrm{V}$ are present in the residual fuel which forms the compound having a low melting point. Corrosion is initiated by these low melting compounds as they get deposited on the surface of the material. These melting compounds react with oxygen to form $\mathrm{Na}_{2} \mathrm{SO}_{4}$ and $\mathrm{V}_{2} \mathrm{O}_{5}$. These compounds are known as ash. Protective oxide layer is deteriorated by these molten compounds during the boiler/gas turbine operations [5,6]. Shut down of plant is due to the hot corrosion of boiler steels tubes at elevated temperature. Besides the shutdown of plants there is loss of thermal efficiency and wastage of material which causes the expenditure of billions of dollars on the machine, equipments and corroded structure. Also human injury or loss of life can happens due to the premature failure of component. The inability to completely eliminate the problem of hot corrosion results in finding the different ways to minimize its effects on metal and alloy steel at elevated temperatures $[7,8]$.

Inability of conventional steels to resist hot corrosion at elevated temperature in thermal power plants provides a pathway for researchers to research on different coating materials and methods to resist erosion and corrosion of boiler steel tubes. From the different methods thermal spray coating techniques has significant effect on reducing the hot corrosion and increasing the life of components. In recent past this techniques has increased its importance. As a thermal spray process is flexible, cost effective and super quality of microstructure is produced its is widely used in the industries [9]. Coating produced by thermal spray method doesn't have any specific limitation with respect to the base composition. With a few millimeter thickness, coating of high hardness can be produced [10]. For protection of boiler components HVOF, plasma, arc and flame method are mostly used. Due to relatively higher in cost plasma method is preferred less and also due to remelting flame method is rarely used [11]. To increase the corrosion resistance researchers used HVOF technique, thermal spray technique and D-gun spray technique to produce hard faced coating. This following part of paper explained the work done by researcher on thermal spray coatings.

\section{STUDIES ON THERMAL SPRAY COATING}

Kamal et al. [12] studied the performance of $\mathrm{NiCrAlY}+0.4$ wt. \%CeO2 coating on super alloys. They used Detonation-Gun spray method for coating on superni 75 superni 718 and superf $800 \mathrm{~h}$. They incorporate the rare earth metal such as $\mathrm{CeO} 2$ in coating to enhance the corrosion protection. Coating composition Ni-22Cr-10Al$1 \mathrm{Y}$ is used on the substrate.the result was examined using weight change, $\mathrm{X}$ ray diffraction, SEM/EDAX X-ray mapping, Cross sectional technique. The bare specimen show more weight gain as compared to the coated specimen. XRD analysis detected the major and minor phase as $\mathrm{CrS}, \mathrm{NiO}, \mathrm{Cr} 2 \mathrm{O} 3$ and $\mathrm{Al} 2 \mathrm{O} 3$. It was identified that $\mathrm{CeO} 2$ was uniformly distributed on the substrate which help in increase in corrosion protection. Bare specimen 
undergoes higher corrosion where as coating specimen least. Coated superf $800 \mathrm{H}$ showed higher corrosion resistance than the three superalloy.

Chatha et al. [13] observed the behavior of $\mathrm{NiCr}$ coating on T-91 boiler steel in Platen Superheater of coal fired boiler. High velocity oxygen fuel method is used for coating the substrate. The substrate are placed for 15 cycle where each cycle consist of $100 \mathrm{~h}$ cycle and $1 \mathrm{hr}$ of cooling at ambient temperature. The results were studied by using weight change technique, XRD technique, SEM/EDS and cross sectional analysis. Using these techniques it was observed that bare T-91 steel form porous oxide scale, higher weight gain as compared to coated steel. XRD analysis showed that bare steel had higher content of Ferrous oxide whereas coated steel had higher content of chromium oxide which protect the steel from corrosion. Cross sectional analysis shows that bare steel had cracked, porous, thick loosely bounded scale where as coated steel has continuous, dense coating without any degradation.

Chatha et al. [14] investigated the coating resistance behavior of $\mathrm{NiCr}$ and $\mathrm{Cr} 3 \mathrm{C} 2-\mathrm{NiCr}$ coating on $\mathrm{T}-91$ boiler steel at $750^{\circ} \mathrm{C}$. For coating High velocity oxy fuel method is employed. The substrate was place inside the molten salt environment (Na2SO4-60\%V2O5) at $750^{\circ} \mathrm{C}$ for 50 cycle each cycle consist of ihr of heating and $20 \mathrm{~min}$ of cooling in air. The results were observed using the weight change measurement, cross sectional analysis, SEM/EDAX analysis, X-ray diffraction, XRD analysis technique. It was seen that uncoated specimen was experienced higher weight gain due to the formation of unprotective iron oxide as the major phase. It was found that $\mathrm{NiCr}$ reduced the weight gain more than the $\mathrm{Cr} 3 \mathrm{C} 2-\mathrm{NiCr}$. Hence it reveals that $\mathrm{NiCr}$ coating on T-91 steel is better than $\mathrm{Cr}_{3} \mathrm{C}_{2}-\mathrm{NiCr}$ with HVOF method. Thus both the coating help in controlling the hot corrosion Jagadeeswaran et al. [15] investigated the hot corrosion of $\mathrm{Al} 2 \mathrm{O} 3+\mathrm{CoCrAlTaY}$ coating on Ti-31 alloy in salt environment. High velocity oxygen fuel method is used for coating the substrate. Experiment is performed under the salt environment condition of 50\% V2O5 and 50\% Na2SO4 at $800^{\circ} \mathrm{C}$. Results were obtained using the XRD, SEM/EDS and weight change measurement technique. It was found that uncoated substrate showed a high gain in weight change measurement and high content of oxides whereas coated substrate had low change in weight measurement and high content of chromium oxide layer which protect the substrate from the further oxidation.

Bhatia et al. [16] observed the performance of $75 \% \mathrm{Cr} 3 \mathrm{C} 2-$ $25 \% \mathrm{NiCr}$ coating on $\mathrm{T}-91$ steel at different operating temperature. Coating was performed using High velocity oxy fuel method. The coating produced on the specimen was uniform, dense and adherent with less than $2 \%$ porosity. The specimens were placed in the corrosive environment of $\mathrm{Na}_{2} \mathrm{SO}_{4}-60 \% \mathrm{~V}_{2} \mathrm{O}_{5}$ for 50 cycle, each cycle consist if $1 \mathrm{hr}$ heating at given temperature i.e 550, 700, 800 in furnace and 20 minute of cooling at ambient temperature. The result were obtained using the visual analysis, thermo gravimetric technique, XRD, SEM/EDS, and cross sectional analysis techniques. The uncoated specimen show the higher weight gain as compared with the coated specimens at all the operating temperatures. It was also noted that uncoated specimen has irregular scale, cracks and spallings whereas coating specimen has uniform and less or negligible cracks. Reason behind the coating resistance was oxides and spinels of nickel-chromium. Hence it was found coating provides better corrosion resistance than the uncoated T-91 sample.

Singh, Singh [17] studied to find out the effect of erosion and corrosion of $\mathrm{Al} 2 \mathrm{O} 3$ coating on $\mathrm{T}-91$ steel at elevated temperature in actual boiler environment. Detonation gun sprayed method is used for coating the substrate. The coated and uncoated specimen was placed in boiler for 10 cycles and results were examined using thermo gravimetric technique and SEM/EDAX. After the analysis it was found that weight change in uncoated specimen was more than that of coated specimen, however change in weight is less. SEM/EDAX show that coated specimen shows presence of $\mathrm{Al}, \mathrm{O}, \mathrm{Zr}, \mathrm{Si}$ whereas $\mathrm{Fe}$ was only found in uncoated specimen.

Singh et al. [18] studied the coating resistance of $\mathrm{Cr} 3 \mathrm{C} 2-$ $\mathrm{NiCr}$ coating, Stellites- 6 and Stellites- 21 on grade A-1 steel boiler. Coating was performed using detonation gun sprayed method on three substrate one by one. The experiment is performed for 10 cycles each cycle consist of $100 \mathrm{hr}$ of heating at $900^{\circ} \mathrm{C}$ and $1 \mathrm{hr}$ of cooling at ambient temperature. The result were examined using the thermo gravemetric technique, SEM/EDS, weight change measurement and cross sectional analysis. It was found that bare substrate undergoes more corrosion as it had high percentage of iron oxide whereas coated substrate had higher percentage of chromium oxide, nickel oxide, cobalt oxide which prevent the substrate from corrosion.

Singh et al. [19] studied the coating effect of Ni3Al and $\mathrm{TiO} 2$ coating on T91 boiler tube steel in simulated boiler environment at $900^{\circ} \mathrm{C}$. HVOF method is used for coating on the substrate T-91 steel. Specimen was placed in molten salt environment for 50 cycle. The oxide scale of T-91 steel tubes is examined using XRD Technique. It was found that uncoated specimen has $\mathrm{Fe} 2 \mathrm{O} 3, \mathrm{Fe} 3 \mathrm{O} 4, \mathrm{Cr} 2 \mathrm{O} 3$ as a main phase where as coated specimen has $\mathrm{NiO}, \mathrm{Al} 2 \mathrm{O} 3$ as a major phase while $\mathrm{Fe} 2 \mathrm{O} 3$, $\mathrm{Fe} 3 \mathrm{O} 4$ as a minor phase. $\mathrm{TiO} 2$ was found to be most protective then $\mathrm{NiAlO} 3$ as $\mathrm{NiO}$ had loose structure thus leads to more pores result in increase in corrosion. Hence the coating provides the protection from the corrosion environment.

Singh et al. [20] investigated the thermal spray coating of NiCrAlY coating on T-91 steel . High velocity oxygen fuel method is used for coating the substrate. Coated and uncoated specimen are placed in $\mathrm{SiC}$ furnace for 50 cycle each cycle consist of one hour heating and 20 minute cooling. The results were analyzed using weight change technique, SEM, EDS and $\mathrm{X}$ ray diffraction technique. It 
was found that uncoated substrate exhibit weight gain during oxygen study, intense spalling and peeling off scale. $\mathrm{Fe} 2 \mathrm{O} 3$ is formed on the uncoated substrate and EDS analysis reveals $\mathrm{Fe}$ and $\mathrm{O}$ as major element which forms Fe2O3. On the other hand coated substrate showed negligible weight gain and formation of $\mathrm{Cr} 2 \mathrm{o} 3$ which reveals Chromium oxide as the major phase which prevent corrosion. $\mathrm{Cr}, \mathrm{Al}$, Ni was main element where as $\mathrm{Fe}$ was minor element in coated substrate. Hence NiCrAlY coating showed significant role in controlling the hot corrosion.

Chatha et al. [21] studied the coating performance of 75 $\mathrm{Cr} 3 \mathrm{C} 2-25 \mathrm{NiCr}$ coating on $\mathrm{T}-91$ boiler tube steel in coal fired boiler at $900^{\circ} \mathrm{C}$. High velocity oxy-fuel method is used for coating the T-91 substrate. Coated and uncoated substrate were place inside the steel boiler for 15 cycles each cycle consist of $100 \mathrm{hr}$ of heating and $1 \mathrm{hr}$ of cooling at ambient temperature. The results were examined using Xray mapping, SEM/EDS, cross sectional analysis technique. It was seen that internal oxidation attack at inside the substrate and corrosion scale formation result in metal loss in uncoated T-91 steel substrate. The coated substrate on other side finds no internal crack and no corrosion formation and showed well adherence property to boiler tube steel. Hence it reveals that coating helps in preventing the hot corrosion.

Sidhu et al. [22] investigated the corrosion resistance of 93(WC-Cr3C2)-7Ni, 75Cr3C2-25NiCr, 83WC-17Co and $86 \mathrm{WC}-10 \mathrm{Co}-4 \mathrm{Cr}$ coating, on $\mathrm{T}-91$ steel. Coating was employed using the High velocity oxy-fuel method. The uncoated and coated substrate were placed inside the coal fired boiler for 10 cycle, each cycle consist of $100 \mathrm{hr}$ of heating at $900^{\circ} \mathrm{C}$ and $1 \mathrm{hr}$ of cooling at ambient temperature. The result was obtained using the visual examination, SEM/EDS, weight measurement technique, X-ray diffraction. It was found using SEM/EDS that uncoated T91 mainly consisted of iron oxide and chromium oxide which did not prevent the corrosion as iron oxide moves inside the substrate and cause corrosion where as coated specimen were having major phase as chromium, nickel, cobalt, tungsten as major phase and absent of iron oxide thus it reveals that it prevent the corrosion. Hence it is found that coating helps in preventing the hot corrosion and coating shows the order of resistance as 93(WC-Cr3C2)$7 \mathrm{Ni}>86 \mathrm{WC}-10 \mathrm{Co}-4 \mathrm{Cr}>83 \mathrm{WC}-17 \mathrm{Co}>75 \mathrm{Cr} 3 \mathrm{C} 2-25 \mathrm{NiCr}$.

Jiang et al., [23] discussed corrosion resistance behavior of Fe based amorphous coating. Coating method used is Plasma spray jet method. The coated and uncoated substrate was placed in salt environment of $70 \% \mathrm{Na} 2 \mathrm{SO} 4-30 \mathrm{~K} 2 \mathrm{SO} 4$ at $700^{\circ} \mathrm{C}$ for $84 \mathrm{hr}$ in coal fired boiler. The results were obtained using the weight change measurement, SEM/EDS, cross sectional analysis techniques. It was noted that bare substrate undergoes corrosion at early stage of cycle as analyzed by weight change measurement but coated substrate show little gain in weigh but at later there was negligible weight gain and corrosion was negligible as compared to bare substrate. It was also noted that if the coating thickness lies between the range of $270-380 \mu \mathrm{m}$ there was effective protection to the coated substrate. In this no cracks, spallation was found on the substrate which protects the interior of substrate from the corrosive medium.

Chatha et al., [24] investigated application and performance of thermal spray coating of $\mathrm{Cr} 3 \mathrm{C} 2-\mathrm{NiCr}$ under various environments for erosion and corrosion. Mechanical and microstructure properties of carbide coating are discussed. With plasma spray, HVOF and detonation gun method carbide coating is deposited successfully. At elevated temperature, coating resistance of carbide coating is very high. With thermal sprayed coating, at splat boundaries voids are formed through which coating were attacked as concluded by author.

Niranatlumpong et al., [25] studied about failure occurred formation of oxides by plasma spray method on $\mathrm{Ni} \mathrm{Cr}$ alloys overlay coatings. They have observed that if the coating procedure is done on 1100 degree $\mathrm{C}$ and with maximum required time more than 100 Hours then coating failures may result a sub parabolic behavior develops in coating, an Initial spallation occurs by de-lamination within layers during cooling. With relatively plasma sprayed coating the internal oxidation also arises and may lead to the aluminum depletion in aluminum alloys. As oxidation tests are performed in thermal gravimetric assembly .results shows that oxidation rate was more until alumina layer is developed at intermediate exposure periods the results are better for coating as they withstand with high temperature and pressure. Testing is done by XRD technique.

Singh et al., [26] experimented on corrosion behavior of plasma sprayed $\mathrm{Ni}_{3} \mathrm{Al}$ coating on Steel in oxidation and molten salt environment at $900^{\circ} \mathrm{C}$. They considered three types of material GrAl, Low Carbon steel T-11 and medium carbon steel T-22 specimens from boiler tubes. Specimens are polished with $\mathrm{Al}_{2} \mathrm{O}_{3}(60 \mu \mathrm{m}$ Grit $)$ before coating is done by nickel and aluminum of $3: 1$ of quantity of grits and applied with plasma spray method in this argon was used as shielding gas and powder carrying gas $\mathrm{Ni}-20 \mathrm{Cr}-10 \mathrm{Al}$ powder $(150 \mu \mathrm{m})$ is used. Tested with XRD, SEM and hardness is tested by micro hardness tester. Results tells us that pre coating of aluminum done at $250^{\circ} \mathrm{C}$ prevents the inter formation of oxide layer at elevated temperature. In molten salt testing environment $(\mathrm{Na} 2 \mathrm{So} 4)$ at $900^{\circ} \mathrm{C}$ the weight gain by $\mathrm{T}-11$ material was less as compared to $\mathrm{T}-22$ material. It was $2 / 3$ of $\mathrm{T}-22$. GrAl gains $1 / 7$ of $\mathrm{T}-22$ material in 50 Cycles. On GrAl found formation of $\mathrm{Fe}_{3} \mathrm{O}_{4}$ on its peaks and on $* \mathrm{t}-22$ it was not formed observed in XRD. As $\mathrm{NiO}$ and $\mathrm{Al} 2 \mathrm{O} 3$ formed on all steel components. GrAl are corroded in molten salt environment and and On T-22 the substrate material forms the oxidized film below coating. It is observed as the nickel and aluminum are dissolves in surface of material as Chromium withstands and prevents material from corrosion and erosion.

Singh et al., [27] Studied microstructure and mechanical properties of $\mathrm{HVOF}$ sprayed $\mathrm{Cr}_{3} \mathrm{C}_{2}$ coating on the boiler 
tube tubes by using LPG gas as fuel gas. In this various coatings are used and tested such as carbide coating but due to high impact of velocity of flowing gases and fluid it causes failure to these coatings instead of this nickel chromium coating used which with stand with high IMAPCT and high velocity fluids using HVOF process (high velocity oxy fuel) and its structural testing is done by $\mathrm{X}$ ray diffraction techniques such as SEM and XRD techniques .Results are obtained as resistance of corrosion. The critical hardness values of the steels were found to be in the range of 200-280 Hv. This coating range is found to be desire able and durable.

Bala et al., [28] Studied about accelerated hot corrosion of cold spray Ni-50Cr Coating on Boiler steels. Experiment is performed under the aggressive environment of $\mathrm{Na}_{2} \mathrm{So} 4-$ $60 \%$ under cyclic conditions. Boiler Steel Specimen is coated with Ni-50Cr of 60 grit particles $45+-15$ um with high velocity Cold spray process of coating and testing methods were XRD Techniques material was mainly used was T-22 Mostly used in boilers and steam turbines these coatings prevents from formation of $\mathrm{Fe}_{2} \mathrm{O}_{3}$ on the surface of $\mathrm{T}-22$ material. Testing techniques are used $\mathrm{X}$ ray technique as average thickness was 339 micro meter with hardness range of 282-419 $\mathrm{Hv}$. Is performed about 50 cycles at 900 $\operatorname{deg} \mathrm{C}$. as this is observed that bare specimen has very less life span as it get corroded and eroded than coated one

Sidhu et al., [29] studied about hot corrosion HVOF sprayed $\mathrm{Cr}_{3} \mathrm{C}_{2}-\mathrm{Ni} \mathrm{Cr}$ and $\mathrm{Ni}-20 \mathrm{Cr}$. Coating on nickel based super alloy in the molten salt environment of $\mathrm{Na}_{2} \mathrm{So}_{4} 60 \%$ at 900 deg C" of temp the 45 micro meter grit was used for coating at 50 cycles as each cycles about of 1 hour. The amount of salt coating was kept in the range of 3.0- 5.0 $\mathrm{mg} / \mathrm{cm}^{\wedge} 2$. And kept it in oven for $3-4$ Hours and thermo gravimetric method is used to study the kinetics of corrosion after that testing is done by XRD and SEM techniques. The results are obtained is $\mathrm{Ni}-20 \mathrm{Cr}$ coating was better then $\mathrm{Cr}_{3} \mathrm{C}_{2}-\mathrm{NiCr}$ coating. The formation of oxides of nickel and chromium blokes the pores os the surface of workpiece so that oxygen could not react even at high temperature when Moisture of environment is present in it.

Kamal et al., [30] at al studied about hot corrosion behavior of detonation gun sprayed $\mathrm{Ni} \mathrm{Cr}$ coatings on fe (Iron) based Super alloys in $\mathrm{Na}_{2} \mathrm{So}_{4}$ Environment at 900 Degree C. The coatings are done with the porosity less than $0.8 \%$. This coating helps in prevention of fusion of gases at very high temperature such as $900^{*} \mathrm{C}$ and above by making a layer on the surface of material. The thermo gravimetry technique is used in molten salt $\mathrm{Na}_{2} \mathrm{So}_{4}$ at 900 environments with 100 cycles in silicon carbide furnace with 20 min cooling time. They used XRD tests to study the microstructure of grains of materials after putting it in to corrosive environment, as Results are obtained as bare element gets corroded in very less time as compared to coated one in high temperatures.

Kumar et al., [31] Studied about hot corrosion of micro structurally different sections of $2.25 \mathrm{Cr}-1 \mathrm{Mo}(\mathrm{T}-22)$ boiler tube welding. this study explains that even welded portions gets oxidized under molten salt $\mathrm{Na} 2 \mathrm{So} 4-60 \% \quad \mathrm{~V}_{2} \mathrm{O}_{5}$ environment in boiler at $900 \%$.the welding base metal is tungsten which gets easily oxidized under this environments at very higher rates can be studied by $\mathrm{X}$ ray techniques of various phase change and oxide formations. For testing the T-22 material is placed in thermal power plant environment. As tubes of this materials are with TIG Welding as weld metal shows the ferrite, pearlite and bainite formation on slow cooling. In the region of molten salt the spallation of oxide layer is found to formed on the boundaries as cycles and temperature increases simultaneously. XRD inspection shows that formation of $\mathrm{Fe}_{2} \mathrm{O}_{3}$ on the weld portions at heat affected zones as chromium should be added with electrode to minimize the weight gain due to corrosive environment and to stop corrosion and erosion.

Jayanathan et al., [32] has been studied about hot corrosion studies of detonation gun sprayed coating Ni Cr Al Alloy + 0.4 wt. $\% \mathrm{CeO}_{2}$ coated super alloys in environment of molten salt they have taken three super alloys namely Superni 75 , superni 718 and superfer $800 \mathrm{H}$ are coated with $\mathrm{M} \mathrm{Cr} \mathrm{Al}$ materials as $\mathrm{m}$ are mainly Nickel/cobalt or combination of both these are coated in the molten salt environment of $\mathrm{Na}_{2} \mathrm{So}_{4}$ with $0.4 \%$ of cerium oxide $\mathrm{CeO}_{2}$. Coating is done with $\mathrm{D}$ Gun Spray Process. As previously done experiments showed that use of cerium improves the efficiency of aluminide coating and prevents the dry sand erosion and corrosion in dilute $\mathrm{H}_{2} \mathrm{So}_{4}$ and $\mathrm{Nacl}$ Solution. It reduce the rate of hot corrosion attack at elevated temperatures around $1000^{\circ} \mathrm{C}$. as it forms the $\mathrm{CeVO}_{4}$ on the material surface. These micro structural characteristics are studied from FE-SEM / EDAX , X ray mapping and XRD techniques to study corrosion mechanism. Results shows that during testing that the bare superfer $800 \mathrm{H}$ shown maximum weight gain followed by superni 71 and superni 718 super alloys.and after coating the superifer $800 \mathrm{H}$ showed minimum weight gain. Which indicates that it is prevented from oxidation of surface.

Singh et al., [33] has observed the status of Cr3C2-25 (Ni$20 \mathrm{Cr}$ ) and $\mathrm{Ni}-20 \mathrm{Cr}$ coatings on $\mathrm{T}-22$ boiler steel tube material in boiler. In boiler the temperature goes around $900^{\circ} \mathrm{C}$ and above to save material of boiler tubes they have tested two types of specimen coated with High Velocity Oxy Fuel (HVOF) process in the environment of molten salt $\left(\mathrm{Na}_{2} \mathrm{So}_{4}-\mathrm{V}_{2} \mathrm{O}_{5}\right)$ for 50 Cycles at $900^{\circ} \mathrm{C}, 30 \mu$ thick coating is applied. The experimentation is done in boiler of silicon tube furnace. Analysis was done by using XRD techniques shows that formation of $\mathrm{NiO}$ and $\mathrm{Cr} 2 \mathrm{O} 3$ on the surface of specimen. Uncoated specimen $\mathrm{T}-22$ tested gives the result as $\mathrm{Fe} 2 \mathrm{O} 3$ forms at minor peaks of the surface and $\mathrm{Cr}_{2} \mathrm{O}_{3}$ major peaks. The coating prevents this oxidation which erodes the material even at elevated temperatures of $900^{\circ} \mathrm{C}$ and above.

Kumar et al., [34] examined oxidation studies on base metals, weld metals and HAZ regions of TIG weld ments in 2.25Cr-1Mo (T-22) boiler tube under different conditions. 
TIG welding is mostly used to weld two tubes in boiler or turbine blades used of T-22 materials gets corroded in elevated molten salt environments mostly at HAZ. This experiment is studied the formation of layers of oxides in heat affected zones by XRD methods, the HAZ showed more weight gain as due to formation of chromium oxide on the boundaries of HAZ . as to confirmed it cyclic testing is done by 50 repetive cycles followed by cooling process side by side the physical measurements are tested with Digital vernier caliper. In experiment the material is kept in alumina boat at $1200{ }^{\circ} \mathrm{C}$ for 6 to 8 hours. Then this boat is kept in furnace of $900^{\circ} \mathrm{C}$ for 1 hour, and then it is taken out and cooled in ambient temperature. For $20 \mathrm{~min}$. then the weight of boat with specimen is measured after each cycle and found that weight is increasing with each repetition of cycle. And changed microstructure after each cycle is observed by XRD method. The colour of oxide layer formed on it was of blackish grey and small spalling was started just after fourth cycle. The cracks are started appearing after $30^{\text {th }}$ cycle. Mostly these cracks were on HAZ.

Singh et al.,[35] studied about behaviour of $\mathrm{Ni}_{3} \mathrm{Al}$ and $\mathrm{TiO}_{2}$ coatings on T-91 material used in boiler tube steel in boiler environment at $900^{\circ} \mathrm{C}$. They have used boiler tube material mostly used ASTM SA 213 its another common name is T91.The two specimen were taken and coated with HVOF process thickness of $250-300 \mu \mathrm{m}$, one with $\mathrm{Ni}_{3} \mathrm{Al}$ and other with $\mathrm{TiO} 3$. after coating the material are kept in the atmosphere of molten salt $\mathrm{Na}_{2} \mathrm{So}_{4}$ with $60 \%$ of $\mathrm{V}_{2} \mathrm{O}_{5}$ at $900^{\circ} \mathrm{C}$ with reparative cycles about 50 at 1 hour of heating and after each cycle the material is kept under 20 ,minutes of cooling at Room temperature. It is found that $\mathrm{Ni3 \textrm {Al }}$ coating was very useful as it decreases the corrosion rate at $900^{\circ} \mathrm{C}$ temperature in molten salt atmosphere and protective than $\mathrm{TiO}_{3}$ coating. $\mathrm{X}$ ray Diffraction XRD, Scanning spectroscopic analysis SEM techniques are used to study the behavior of coatings and rate of corrosion during experiment. The results shows that $80 \mathrm{Ni}-20 \mathrm{Cr}$ results better than $75 \mathrm{Cr}_{3} \mathrm{C}_{2}-25(\mathrm{Ni}-20 \mathrm{Cr})$ coating. This experiment is performed in thermal plant. The process of Weight change is observed through thermo grevimetric process.

Mangla et al., [36] Studied about behavior of HVOF and plasma sprayed $\mathrm{Ni}-20 \mathrm{Cr}$ coated $\mathrm{T}-22$ steel in actual coal boiler environment. They tested the T-22 material or steel with two different methods one with HVOF and Other is plasma spray method to coating of t-22 with $\mathrm{Ni}-20 \mathrm{Cr}$. The testing is performed in the actual boiler burned with coal field. The uncoated material makes spelled oxide layer formation and by both coating techniques this spelled layer is not formed at boiler coal field environment at high temperatures of $900^{\circ} \mathrm{C}$. Coating of $\mathrm{Ni}-20 \mathrm{Cr}$ makes the layers of $\mathrm{NiO}, \mathrm{Cr}_{2} \mathrm{O}_{3}$ on the surfaces as shown by XRD and EDS testing. This is confirmed as the HVOF process resulted better corrosion resistance than plasma spray method of coating and weight was less of deposition of material by $77.8 \%$ to $65 \%$ as compared to deposition in plasma coated material

\section{CONCLUSION}

In this paper, detailed literature review has been done for corrosion behavior of thermal spray coating on boiler steels at elevated temperatures and the following conclusions are made; For high temperature environment applications corrosion has been found as a serious problem in the degradation of boiler steel tubes. In the recent past, various coatings techniques are used on the surface of steel by the structure to resist the corrosion at elevated temperatures as studied in the literature survey. D gun spray technique, HVOF technique and thermal spray technique has produced hard faced coatings to increase the corrosion resistance. By using this techniques and sophisticated coating system 100 $\%$ defect free steels are not possible to achieve as the coating techniques produced the micro pores on the layer of coating and this acts as a path way for the corrosion species to attack on the substrate resulting in spallation and many local micro cracks on the steel, hence there is a scope to enhance over improve these coatings by decreasing the defect and reducing the porosity. There is a future scope for further research work in this area to minimize these defects.

\section{REFERENCES}

[1] D. Gond, V. Chawla, D. Puri and S. Prakash, "High Temperature Corrosion Behavior of T-91 and T-22 Bare Steel in $75 \mathrm{wt} \% \mathrm{Na}_{2} \mathrm{SO}_{4}+25 \mathrm{wt} \% \mathrm{NaCl}$ Molten Salt Environment at $900^{\circ} \mathrm{C} "$, Journal of Mineral and Material Characterization and Engineering, Vol. 9, pp. 593-606, 2010.

[2] S. Srikanth, B. Ravikumar, SK. Das, et al. "Analysis offailure in boiler tubes due to fireside corrosion in a waste heat recovery boiler", Eng Fail Anal, Vol. 10; pp. 59-66, 2003.

[3] G.J. Santoro, F.J Kohl and C.A. Stems, et al., "Experimental and deposition rates from salt seeded combustion gases of a mach 0.3 burner rig, NASA Technical Paper; 2225, 1984.

[4] M.A DeCrescente, N.S Bornstein, "Formation and reactivity thermodynamics of sodium sulfate with gas turbine alloys", Corrosion, Vol. 24, pp. 127-133, 1968.

[5] S Kamal, R Jayaganthan, S Prakash, "Evaluation of cyclic hot corrosion behaviour of detonation gun sprayed $\mathrm{Cr} 3 \mathrm{C} 2-25 \% \mathrm{NiCr}$ coating on Nickel and iron based superallys", Surf Coat Tech, Vol. 203, pp. 1004-1013, 2009.

[6] M. Ramesh, S. Parkash, S. Nath, et al., "Solid particle erosion of HVOF sprayed WC-Co/NiCrFeSiB coatings", Wear, Vol. 269, pp. 197-205, 2010.

[7] HS. Sidhu, BS. Sidhu, S. Parkash, "Mechanical and microstructure properties of HVOF Sprayed WC-Co and $\mathrm{Cr} 3 \mathrm{C} 2-\mathrm{NiCr}$ coating on boiler tube steels using LPG as the fuel gas", J. Mater Process Tech", , Vol. 171, pp. 77-82, 2006.

[8] MA. Uusitalo, PMJ. Vuoristo, TA. Mantyla, "High temperature corrosion of coating and boiler steel in oxidizing chlorine containing atmosphere", Mater Sci Eng, Vol. 346, pp. 168-177, 2003.

[9] R. Sivakumar, SV. Joshi, "Protective Coating by Plasma Spraying: A Review", T Indian Ceram Soc, Vol. 50, pp. 1-14, 1991.

[10] K. Szymanski, A. Hernas, G. Moskal, et al., "Thermally sprayed coating resitant to erosion and corrosion of power plant boiler- A Review", Surf Coat Tech; Article in press, 2014.

[11] A. Lopez, M. Proy et al., "high temperature corrosion behavior of Ni$50 \mathrm{Cr}$ coating deposited by HVOF technique on low alloy ferritic steel", Mater des, Vol. 59, pp. 94-102, 2014.

[12] S. Kamal, R. Jayaganthan and S. Parkash, "Hot Corrosion Studies of Detonation-Gun-Sprayed NiCrAlY +0.4 wt. $\%$ CeO2 Coated Superalloys in Molten Salt Environment", Journal of Materials Engineering and Performance, Vol. 20, pp. 1068-1077, 2010.

[13] S. Chatha, H. Sidhu and B. Sidhu, "High Temperature Hot Corrosion Behaviour of NiCr and $\mathrm{Cr} 3 \mathrm{C} 2-\mathrm{NiCr}$ Coatings on T91 Boiler Steel in 
an Aggressive Environment at $750{ }^{\circ} \mathrm{C}$, Surface \& Coatings Technology, Vol. 2, pp. 3839-3850, 2012.

[14] S. Chatha, H. Sidhu, B. Sidhu, "High Temperature Hot Corrosion Behaviour of NiCr and Cr3C2-NiCr Coatings on T91 Boiler Steel in an Aggressive Environment at $750{ }^{\circ} \mathrm{C}$ ", Surface \& Coatings Technology, Vol. 2, pp 3839-3850, 2012.

[15] N. Jagadeeswaran, M. Ramesh, K. Bhat, "Hot Corrosion Studies on As-received and HVOF SprayedAl2O3+CoCrAlTaY on Ti-31 Alloy in Salt Environment, International Conference On Design and Manufacturing, Procedia Engineering, Vol. 3, pp-1013-1019, 2013.

[16] R. Bhatia, H. Singh, B.S Sidhu, "Hot Corrosion Studies of HVOFSprayed Coating on T-91 Boiler Tube Steel at Different Operating Temperatures", Journal of Materials Engineering and Performance, Vol. 23, pp 493-505, 2013.

[17] G. Singh, T. Singh, "To Study High Temperature Erosion-Corrosion of Detonation Gun Sprayed $\mathrm{Al}_{2} \mathrm{O} 3$ Coated and Uncoated T-91 Boiler steel in Actual Environment of Boiler", International Journal of Science and Research (IJSR), Vol. 3, pp261-264, 2014.

[18] B. Singh, A. Jain, V. Chawla, "Evaluation of Erosion-Corrosion Resistance of Some Detonation Gun Sprayed Coatings on Grade A-1 boiler Steel in a Coal Fired boiler", International Journal of Engineering, Vol. 2, pp. 13-18, 2015.

[19] S. Singh, K. Goyal, R. Goyal, "Performance of Ni3Al and TiO2 Coatings on T91 Boiler Tube Steel in Simulated Boiler Environment at $900^{\circ} \mathrm{C}^{\prime \prime}$, Journal of Thin Films, Coating Science Technology and Application, Vol. 3 ,pp-27-34, 2016.

[20] G. Singh, N. Bala, V. Chawla, "High Temperature Oxidation Behaviour of HVOF Thermally Sprayed NiCrAlY Coating on T-91 Boiler Tube Steel", 6th International Conference of Materials Processing and Characterization, Proceedings, Vol. 4 , pp. 5259$5265,2016$.

[21] S. Chatha, H. Sidhu, B. Sidhu, "Performance of 75Cr3C2-25NiCr Coating Produced by HVOF Process in a Coal-Fired Thermal Power Plant”, Advanced Materials Research, ISSN: 1662-8985, Vol. 2, pp. 88-100, 2016.

[22] V. Sidhu, K. Sidhu, Goyal, R. Goyal, "An Investigation of Corrosion Resistance of HVOF Coated ASME SA213 T91 Boiler Steel in an Actual Boiler Environment", Anti-Corrosion Methods and Materials, published online, 2017.

[23] C. Jiang, W. Liu et al., "The Corrosion Behaviours of PlasmaSprayed Fe Based Amorphous Coatings", Surface Engineering, published online, 2017.

[24] SS. Chatta, HS. Sidhu, BS. Sidhu, "Characterization and corrosion erosion behavior of carbide based thermal spray coating", Journal of Minerals and Material Characterization and Engineering, Vol. 11, pp. 569-579, 2012.

[25] P. Niranatlumpong, H.E. Evans, and B. Ponton, "Failure of protected oxide on plasma sprayed on $\mathrm{Ni} \mathrm{Cr}$ Alloys Overlay Coatings", Oxidation of metals, Vol. 53, pp. 3-4, 2000.
[26] B. Singh, and S. Parkash, "Evaluation of the corrosion Behavior of plasma sprayed $\mathrm{Ni} 3 \mathrm{Al}$ coating on Steel in oxidation and molten salt environment at $900^{\circ} \mathrm{C}$ ", Surface Coating Technology, Vol. 166, pp. 89-100, 2003.

[27] H. Singh, B. Singh and S. Prakash, "The microstructure and mechanical properties of $\mathrm{HVOF}$ sprayed $\mathrm{Cr} 3 \mathrm{C} 2$ Coating on the boiler tube tubes" Journal of material processing technology, Vol. 171, pp. 77-82, 2006.

[28] N. Bala, S. Parkash, and H. Singh, "Accelerated hot corrosion of cold spray Ni-50Cr Coating on Boiler steels", Materials and design, Vol. 31, pp. 244-253, 2006.

[29] T. Sidhu, S. Parkash, and R.D. Aggarwal, "Hot corrosion HVOF sprayed $\mathrm{Cr} 3 \mathrm{C} 2-\mathrm{Ni} \mathrm{Cr}$ and $\mathrm{Ni}-20 \mathrm{Cr}$.on nickel based super alloy in the molten salt environment of Na2So4 60\% at 900 deg C', Surface coating and Technology, Vol. 201, pp 792-800, 2006.

[30] S. Kamal, S. Parkash, S. Kumar, and R. Jayanathan, "Hot Corrosion Behavior of Detonation Gun sprayed Ni Cr coatings on fe (Iron) based Super alloys in Na2So4 Environment at 900 Degree C", Journals of alloys and compounds, Vol. 463, pp 358-372, 2008.

[31] R. Kumar, V. Tewari, and S. Parkash, "Hot Corrosion of Micro structurally different regions of 2.25Cr-1Mo (T-22) Boiler tube Weldment"., Journals of Material Engineering and Performance, Vol. 18, pp 959-965, 2009.

[32] R. Jayanathan, S. Kamal, and S. Parkash, "Hot Corrosion studies of Detonation gun sprayed $\mathrm{Ni} \mathrm{Cr} \mathrm{Al}$ Alloy + 0.4 wt.\% CeO2 coated Super alloys in molten salt Environment", Journals of Material Engineering and Performance, Vol. 20, pp. 1068-1077, 2011.

[33] S. Singh, K. Goyal, and R. Goyal, "performance of $\mathrm{Cr} 3 \mathrm{C} 2-25$ (Ni$20 \mathrm{Cr}$ ) and $\mathrm{Ni}-20 \mathrm{Cr}$ coatings on T-22 Boiler steel tube material in Stimulated Boiler Environment", Journals of Thin Films, Coatings Science Technology and Applications, Vol. 3, pp, 19-26, 2016.

[34] R. Kumar, V. Tweari, and S. Parkash, "Oxidation Studies on base Metal, Weld Metals and HAZ regions of TIG weldments in $2.25 \mathrm{Cr}$ 1 Mo (T-22) boiler Tube under cyclic conditions", Vol. 86, pp. 407$415,2016$.

[35] S. Singh, K. Goyal, and R. Goyal, "Performance of Ni3Al and TiO2 coatings on T-91 material of Boiler tube steel in Stimulated boiler environment at $900^{\circ} \mathrm{C} "$. , Journals of Thin Films, Coatings Science Technology and Applications, Vol. 3, pp 27-34, 2016.

[36] A. Mangla, V. Chawla, and G. Singh, "Comparative hot Corrosion behavior of HVOF and Plasma Sprayed Ni-20Cr Coated T-22 Steel in Actual Coal Field Boiler Environment", Journals of Engineering Science and Researches, ISSN 2348-8034, 2017. 